UDC 542.941.8/547.59

\title{
OXIDATIVE DEHYDROGENATION OF METHYLCYCLOPENTANE TO METHYLCYCLOPENTADIENE-1,3 OVER MODIFIED ZEOLITE CATALYSTS
}

\author{
A.M.Aliyev, M.Ya.Abbasov, U.M.Najaf-Guliyev, Z.A.Shabanova, G.A.Ali-zade, \\ R.Yu.Mirzoeva
}

M.Nagiyev Institute of Catalysis and Inorganic Chemistry, NAS of Azerbaijan

abbasov.mahir@mail.ru

Received 23.05.2019

Accepted 23.12.2019

\begin{abstract}
Selective $\mathrm{C}-\mathrm{C}$ - and $\mathrm{C}-\mathrm{H}$ - bond activations are an important catalytic process to produce various valueadded hydrocarbons oxidative dehydrogenation processes. For producing desired product with a high yield control of reaction pathway through the design of catalyst, fundamental understanding and clarification of reaction mechanism are prerequisite. In this work, we designed heterogeneous catalysts by combining $\left\{\mathrm{Cu}^{2+}(0.5\right.$ mas. $\%), \mathrm{Zn}^{2+}\left(0.2\right.$ mas.\%), $\mathrm{Co}^{2+}(0.1$ mas.\% $), \mathrm{Cr}^{3+}(0.1$ mas. $\left.\%)\right\}$ and clinoptilolite zeolites particles for oxidative dehydrogenation reaction of methylcyclopentane. Depending on the catalyst combination, the reaction pathways of dehydrogenation, ring-opening with isomerization, and ringenlargement with hydrogenation and dehydrogenation of $\mathrm{C}_{5}$-cyclic ring to $\mathrm{C}_{6}$-cyclic ring (i.e., cyclohexane and benzene) can be controlled to produce various products with high yields. The conversion of methylcyclopentane was investigated over $\mathrm{HY}$ zeolite at $360^{\circ} \mathrm{C}$. Catalytic activity of the clinoptilolite in the reaction of selective oxidative dehydrogenation of methylcyclopentane into methylcyclopentadiene has been measured experimentally. Addition of $\mathrm{Zn}$ increases the stability of catalytic activity and induces distinct selectivity changes. When the $\mathrm{Zn}$ content is increased, dehydrogenation of methylcyclopentane to methylcylopentadiene goes through a maximum and deep dehydrogenation of methylcylopentane to benzene remains roughly constant. This study would provide practical and fundamental insight for design of heterogeneous catalyst for controlling reaction pathways.
\end{abstract}

Keywords: methylcyclopentane, catalytic dehydrogenation, methylcyclopenten, methylcyclopentadiene, clinoptilolite.

\section{doi}

\section{Introduction}

The subject of present investigation was the methylcyclopentane fraction of Baku petroleum boiling between 69 and $75^{\circ} \mathrm{C}$, which was subjected to the action of various oxide catalysts and activated clinoptilolite zeolites. It was established that the dehydrogenation of this methylcyclopentane fraction on catalysts and atmospheric pressure led to the formation of methylcyclopentadiene, calculated on the initial methylcyclopentane fraction. This invention relates to a novel catalyst and to the use of this catalyst in the catalytic dehydrogenation of methylcyclopentane to produce methyl-1,3-cyclopentadiene. Throughout the specifications and claims of this application methyl-1,3-cyclopentadiene is used generically to encompass all positional isomers as determined by the position of the methyl group on the cyclopentadiene ring. The invention disclosed and claimed in this application is applicable to all such isomers. Methyl-1,3-cyclopentadiene is an extremely useful compound. It has utility as a bio- logical toxicant and in the preparation of intermediates useful in synthetic resinous compositions. To date, a commercially satisfactory process for the synthesis of methyl-1,3-cyclopentadiene has not been discovered or disclosed and this has hampered the full utilization of this material [1].

Consequently, the dehydrogenation of methylcyclopentane at high temperatures is fundamental to an overall understanding of reactions of cycloparaffins on solid acid catalysts. By using clinoptilolite most of our studies of olefins on this catalyst have been done in the temperature range $300-400^{\circ} \mathrm{C}$. Natural clinoptilolite can be used as an ion exchanger for removal of heavy metals because it has desirable characteristics of high ion exchange selectivity and resistance to different media [2].

Clinoptilolite is a natural microporous material possessing a versatile range of cation exchange properties that are exploited in many industrial processes. Clinoptilolite hails from the heulandite family of zeolites, which shares the same topology of eight- and 10-membered 
ring channels running parallel to the c-axis and an intersecting eight-membered ring channel parallel to the a-axis [3]. Clinoptilolite is used in many industrial fields due primarily to its abundance and cation exchangeability. We have shown that natural clinoptilolite modified with various non-transition elements and transition cations ( $\mathrm{Zn}, \mathrm{Cu}, \mathrm{Co}, \mathrm{Cr}, \mathrm{Mn}, \mathrm{Pd}, \mathrm{Fe}$, etc.). In this work, we have used a natural clinoptilolite with rich deposits in the territory of the Republic of Azerbaijan and uptake of copper(II), cobalt(II), chrome(III), zinc(II) from their single and mixed ion solutions. The mineralogical and chemical properties of the sorption material were carried out by X-ray diffraction, X-ray fluorometry, scanning electron microscopy, and wet analysis. We have applied these cations $\mathrm{Cu}^{2+}, \mathrm{Zn}^{2+}, \mathrm{Co}^{2+}$ and $\mathrm{Cr}^{3+}$ by ion-exchange and indicated that this one is the active catalyst for the reaction of oxidative dehydrogenation of methylcyclopentane. On the basis of experimental kinetic data by using Langmuir-Hindshelwood rate expression we have established that reaction of oxidative dehydrogenation of methylcyclopentane proceeds with the participation of the dissociative adsorbed oxygen. The purpose of the present work is to determine a role of the components of the catalytic system, in order to simplify kinetic studies of the reaction with conjugated dehydrogenation of methylcyclopentane with metal-clinoptilolite. Including the effect of factors such as raw material volume rates, component ratio, temperature and quartz reactor surface conditions on the process running is obtained by us.

\section{Experimental part}

Catalysts were prepared by the ionexchange method, using of Azerbaijan natural clinoptilolite (crystallinity $84.0 \%$ ) and the different metal cations exclusively. Catalysts were prepared by modification of zeolites with metal cations was performed by treatment their initial forms into a solution of chloride salts of the corresponding cations. Before ion exchange, the clinoptilolite has been treated with $0.5 \mathrm{~N} \mathrm{HCl}$. The number of the cations incorporated into the clinoptilolite was determined by ICP-MS Agilent 7700 and it amounted to $(0.1-2) \%$ by weight of the clinoptilolite. The reaction was carried out at $360-400^{\circ} \mathrm{C}$ and atmospheric pressure. Before the reaction, the catalyst was activated in the air $(15 \mathrm{~mL} / \mathrm{min})$ at $300^{\circ} \mathrm{C}$ for $3 \mathrm{~h}$. For clinoptilolite, the catalysts were typically reduced at $300^{\circ} \mathrm{C}$ for $2 \mathrm{~h}$. in a flow of $\mathrm{H}_{2}(10 \mathrm{~mL} / \mathrm{min})$. It was noted that $\mathrm{H}_{2}$ was required in this reaction to prevent coke accumulation. At reaction temperature (typically at $360^{\circ} \mathrm{C}$ ), saturated vapour of methylcyclopentane (Aldrich, $99.5 \%$ ) at was carried by hydrogen (total flow of $15 \mathrm{~mL} / \mathrm{min}$ ) through a fixed bed U-shaped flow reactor made with a quartz tube (outside diameter $D=8 \mathrm{~mm}$ ). We used the catalysts with particle size $0.25-0.63 \mathrm{~mm}$. The reactor is placed in an air electric oven with automatic temperature control. Methylcyclopentane vapours and air mixed with oxygen in the mixer located in a thermostat oven, enter the reactor for the catalysis. Temperature stability is maintained in the oven with a contact thermometer. The temperature in the middle of the catalyst bed is measured with a thermocouple and recorded with the potentiometer. The reaction unit is directly connected to the analysis system through six-way valve allows the analysis of the reaction mixture without loss. The mixture exiting from the reactor gradually passes through the sample loop and is collected in the cooled trap. The analyses of the product of the reactions were also performed by gas chromatography using GC "Agilent 7890" with "Agilent 5975" MS and capillary column HP-5MS (length, $30 \mathrm{~m}$ ) [4].

\section{Results and discussion}

The selectivity and conversion i.e., in the fraction of methylcyclopentane molecules leading to a given product, are shown explicitly in Table. A reaction temperature of $340 \pm 20^{\circ} \mathrm{C}$ was used for the comparison of $\mathrm{Cu}^{2+}, \mathrm{Zn}^{2+}$, $\mathrm{Co}^{2+}, \mathrm{Cr}^{3+}$ and another transition cations. From the table, we can see natural clinoptilolite, mordenite and natural clinoptilolite with modified cations $\mathrm{Zn}^{2+}(\exp 1,2,3)$ show lower catalytic activity in the reaction. After we add natural clinoptilolite cations; $\mathrm{Cr}^{3+}, \mathrm{Cu}^{2+}$ and $\mathrm{Co}^{2+}$ is relatively higher than above mentioned ones (exp. $4,5,6)$. Combination of two cations in natural clinoptilolite; $\mathrm{Cu}^{2+}, \mathrm{Fe}^{3+}, \mathrm{Mn}^{2+}, \mathrm{Pd}^{2+}, \mathrm{Co}^{2+}, \mathrm{Zn}^{2+}$ and $\mathrm{Cr}^{3+}$ increase the efficiency of methylcyclopentadiene from oxidative dehydrogenation of methylcyclopentane reaction (exp 7, 15). From the experimental investigation we show that the clinoptilolite with containing cations $\mathrm{Co}^{2+}$ and $\mathrm{Cr}^{3+}$ more catalytic activity than another combi- 
nation of cations in the reaction $(13,14,15)$. When we add fourth cation $\mathrm{Zn}^{2+}$ in this catalytic system we saw that it causes a considerable increase in the yields of methylcyclopentene and methylcyclopentadiene (exp 16, 17, 18, 19).

Deep dehydrogenation is slower while we add on $\mathrm{Zn}$ than on the other one metals. After we check more catalysts we arrived at a con-

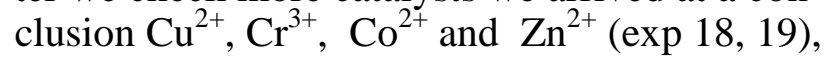
cations with modified clinoptilolite system show more catalytic activity and relatively Fe, $\mathrm{Mn}, \mathrm{Pd}$ cations shows low catalytic activity in the reaction of oxidative dehydrogenation of methylcyclopentane ( $\exp 7-9$ ).

In this work we report the catalytic properties of natural clinoptilolite containing cations $\mathrm{Cu}^{2+}-0.5$ mas \%, $\mathrm{Zn}^{2+}-0.2$ mas $\%, \mathrm{Co}^{2+}-0.1$ mas $\%$ and $\mathrm{Cr}^{3+}-0.1$ mas $\%$ is the active catalyst for the conversion methylcyclopentane into methylcyclopenten and methylcyclopentadiene; a wide range of transition metal composition was used, including those previously investigated over different catalysts.

The activity of the zeolite catalysts in different reactions depends on; crystal structure, nature of cations, method preparation and dis- tribution of cations of metals on a surface of the zeolite. Large, easily accessible surface deposits mainly of volcanoclastic origin, allow clinoptilolite low-cost production by simple excavation. Clinoptilolite is one of the natural zeolites found in abundance in many locations. It is a member of the heulandite group of natural zeolites, being isostructural with the heulandite zeolite, which it differs in having higher Si/Al [5].

The unit cell of clinoptilolite is monoclinic and is usually characterized on the basis of 72 oxygen atoms $(n=36)$ and $m=24$ water molecules, with $\mathrm{Na}^{+}, \mathrm{K}^{+}, \mathrm{Ca}^{2+}$, and $\mathrm{Mg}^{2+}$ as the most common charge-balancing cations. Clinoptilolite is assigned to the same framework heulandite. These units are linked together to form a two dimensional channel structure with elliptical pore openings. Channel A (10-membered ring) and B (8membered ring) are parallel to each other and the c axis of the unit cell, while the $\mathrm{C}$ channel (8membered ring) lies along a axis, intersecting both the A and B channels. Small hydrated cations $\left(\mathrm{Cu}^{2+}, \mathrm{Zn}^{2+}, \mathrm{Co}^{2+}\right.$, and $\left.\mathrm{Cr}^{3+}\right)$ can easily enter the channels of clinoptilolite and compete for the major exchangeable cation sites, designated as $\mathrm{M}(1), \mathrm{M}(2), \mathrm{M}(3)$, and $\mathrm{M}(4)$ [6].

The results of the activity of modified natural clinoptilolite (CL) catalyst in the reaction of oxidative dehydrogenation of methylcyclopentane $\left(T=360^{\circ} \mathrm{C}, V=1500 \mathrm{~h}^{-1}, \mathrm{C}_{6} \mathrm{H}_{12}: \mathrm{O}_{2}: \mathrm{N}_{2}=1.74: 1: 3.72\right)$

\begin{tabular}{|c|c|c|c|c|c|c|c|c|c|c|}
\hline \multirow{2}{*}{$\begin{array}{l}\text { № } \\
\exp \end{array}$} & \multirow{2}{*}{ Catalyst } & \multirow{2}{*}{$\begin{array}{c}\text { Conversion } \\
\text { of } \mathrm{C}_{5} \mathrm{H}_{9} \mathrm{CH}_{3} \text {, } \\
\mathrm{X}, \% \\
\end{array}$} & \multirow{2}{*}{$\begin{array}{c}\text { Selectivity, } \\
\quad S, \%\end{array}$} & \multicolumn{7}{|c|}{ Yield, A, \% } \\
\hline & & & & $\mathrm{C}_{5} \mathrm{H}_{8}$ & $\mathrm{C}_{5} \mathrm{H}_{6}$ & $\mathrm{C}_{5} \mathrm{H}_{7} \mathrm{CH}_{3}$ & $\mathrm{C}_{5} \mathrm{H}_{5} \mathrm{CH}_{3}$ & $\mathrm{C}_{6} \mathrm{H}_{10}$ & $\mathrm{C}_{6} \mathrm{H}_{6}$ & $\mathrm{CO}_{2}$ \\
\hline 1 & $\mathrm{CL}$ & 8.9 & 28.1 & 0.5 & 0.8 & 2.6 & 2.5 & 1.3 & 0.7 & 0.5 \\
\hline 2 & Mordenit & 4.2 & 28.6 & 0.1 & - & 1.7 & 1.2 & 0.3 & - & 0.9 \\
\hline 3 & CL Zn*(0,2) & 17.6 & 21.6 & 0.9 & 0.4 & 3.3 & 3.8 & 3.7 & 4.2 & 1.3 \\
\hline 4 & $\mathrm{CL} \mathrm{Cu} *(0,5)$ & 25.3 & 52.2 & 1.8 & 0.8 & 5.3 & 9.4 & 4.1 & 1.9 & 2.0 \\
\hline 5 & $\mathrm{CL} \mathrm{Co} *(0,1)$ & 38.8 & 34.0 & 2.1 & 1.5 & 9.2 & 13.2 & 4.3 & 2.7 & 5.3 \\
\hline 6 & $\mathrm{CL} \mathrm{Cr*}(0,1)$ & 40.1 & 34.9 & 3.5 & 2.4 & 10.6 & 14.0 & 5.7 & 1.8 & 2.1 \\
\hline 7 & CL Cu Fe $(0,5: 0,25)$ & 29.7 & 21.2 & 2.2 & 1.3 & 4.9 & 6.3 & 3.5 & 4.9 & 6.6 \\
\hline 8 & CL Cu Mn $(0,5: 0,1)$ & 31.9 & 24.1 & 2.7 & 0.4 & 5.8 & 7.7 & 9.7 & 2.4 & 3.2 \\
\hline 9 & CL Cu Pd $(0,5: 0,25)$ & 40.9 & 26.2 & 4.1 & 1.6 & 6.7 & 10.7 & 7.1 & 3.7 & 7.0 \\
\hline 10 & \begin{tabular}{|l|l} 
CL Cu Co $(0.5: 0,5)$ \\
\end{tabular} & 32.8 & 20.7 & 2.4 & 0.8 & 7.3 & 6.8 & 4.9 & 3.1 & 5.5 \\
\hline 11 & $\mathrm{CL} \mathrm{Cu} \mathrm{Cr}(0.5: 0,1)$ & 26.0 & 27.7 & 3.8 & 2.6 & 4.1 & 7.2 & 6.0 & 2.3 & 2.0 \\
\hline 12 & CL Zn Cr $(0.2: 0,1)$ & 39.8 & 27.1 & 5.2 & 3.9 & 4.9 & 10.8 & 7.7 & 4.0 & 3.3 \\
\hline 13 & CL Co Cr (0.1:0.1) & 47.4 & 35.6 & 3.3 & 2.9 & 7.6 & 16.9 & 8.0 & 4.7 & 4.0 \\
\hline 14 & CL Co Cr $(0,5: 0,1)$ & 54.7 & 34.4 & 2.7 & 4.2 & 12.4 & 18.8 & 9.3 & 2.2 & 5.1 \\
\hline 15 & CL Co Cr $(0,5: 0,25)$ & 57.7 & 37.1 & 1.8 & 2.7 & 15.9 & 21.4 & 6.2 & 5.9 & 3.8 \\
\hline 16 & CL Cu Pd Zn (2:1:2) & 44.1 & 33.3 & 2.9 & 1.6 & 10.8 & 14.7 & 3.2 & 4.5 & 6.4 \\
\hline 17 & \begin{tabular}{|l|} 
CL Zn Co Cr \\
$(0.2: 0.5: 0.25)$ \\
\end{tabular} & 45.7 & 49.7 & 3.4 & 2.1 & 4.5 & 22.7 & 2.7 & 2.2 & 8.1 \\
\hline 18 & $\begin{array}{l}\text { CL Cu Zn Co Cr } \\
(2: 2: 1: 0,5)\end{array}$ & 50.0 & 51.8 & 2.8 & 6.3 & 5.8 & 25.9 & 3.4 & 1.1 & 4.7 \\
\hline 19 & $\begin{array}{l}\text { CL Cu Zn Co Cr } \\
(0.5: 0.2: 0.1: 0.1)\end{array}$ & 75.8 & 55.8 & 1.5 & 4.8 & 17.0 & 42.3 & 4.3 & 2.0 & 3.9 \\
\hline
\end{tabular}

* - the figures in brackets indicate the containing exchange cations in mas $\%$. 
The crystal structure shows the existence of three types of structural channels confined byten- and eight-membered tetrahedral ring systems (Figure 1).

However, no detailed single crystal structural studies for $\mathrm{Zn}$ ion-exchanged clinoptilolite ( $\mathrm{ZnCL}$ ) have been undertaken. The conducted by us studies revealed that CL tolerates limited to complete $\mathrm{Zn}$ ion-exchange. The ion-exchange and reduction processes for $\mathrm{Co}^{2+}$ reduction mechanism is complex, indirect, and sensitive to reduction temperature; consequently, $\mathrm{Co}_{n}^{+}$states intermediate between $\mathrm{Co}^{2+}$ and $\mathrm{Co}^{0}$ should be present in the reduced samples.

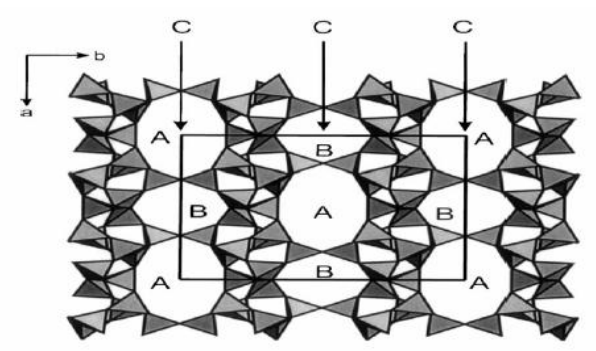

Fig.1.Polyhedron model of clinoptilolite reflected of structure with exchange cations.

We know from the literature a crystal lattice of clinoptilolite consist of three open channels: A, B and C. It from the Figure 1, can be seen the polyhedron model of clinoptilolite, has a fragment of the structure with exchange cations [7].

$\mathrm{A}$ and $\mathrm{B}$ channels are parallel to axis, $\mathrm{C}$ and consist of tencyclic and octocyclic rings. They cross with the third octocyclic channel parallel to the $a$. Hexagonal planers in the structure of clinoptilolite are surrounded with channels $\mathrm{A}, \mathrm{B}$ and $\mathrm{C}$, in which the exchange cations are localized A planar molecule of methylcyclopentane is pentagonal planers surrounded exchange cations in the structure of clinoptilolite.

In clinoptilolite there are four types of places in the localization of exchange cations; they are $\mathrm{M}_{1}$ in channel $\mathrm{A}, \mathrm{M}_{2}$ in channel $\mathrm{B}, \mathrm{M}_{3}$ in $\mathrm{C}$ arranged along axis of a near center of the hexacyclic ring and $\mathrm{M}_{4}-$ place arranged in channel $\mathrm{A}$ in center of inversion. Their quantity is not great. $M_{3}$ is arranged near $M_{1}[8,9]$.

A role of components of the catalytic system in the reaction of oxidative dehydrogena- tion of methylcyclopentane can be explained by analysis of surrounding of the adsorbed molecules of methylcyclopentane with the exchange cations bonded with dissociative adsorbed oxygen, taking into account their bonding energies which can be found by expression [10].

$$
q_{0}=\frac{1}{2}\left(q_{\mathrm{ads}}+500\right)
$$

where $500 \mathrm{~kJ} / \mathrm{mole}$ - energy of dissociation of molecule oxygen, $q_{\text {ads }}$ - heat of adsorption of oxygen the pure surfaces of the polycrystal specimens of transient metals [16]; $q_{\text {ads }}(\mathrm{Cu})=$ $478, q_{\text {ads }}(\mathrm{Zn})=240, q_{\text {ads }}(\mathrm{Co})=418$ and $q_{\text {ads }}(\mathrm{Cr})=$ $753 \mathrm{~kJ} / \mathrm{mole}$. Bonding energies of the components of catalyst with oxygen can be calculated by using formula; $q_{0}(\mathrm{Cu})=489 \mathrm{~kJ} /$ mole, $q_{0}(\mathrm{Zn})=$ $370 \mathrm{~kJ} / \mathrm{g}$-atom, $q_{0}(\mathrm{Co})=459 \mathrm{~kJ} / \mathrm{g}$-atom, $q_{0}(\mathrm{Cr})=$ $612 \mathrm{~kJ} / \mathrm{g}$-atom.

Contingent on the solidity of these bonds propellant force of hydrogen atoms of methylcyclopentane changes. The maximum propellant force of hydrogen atoms of methylcyclopentane is indicated by the oxygen atoms bonded with the component of the catalyst. From experimental data presented in Table and with taking regard to the bonding energies of the components of the catalyst with oxygen atom it is possible to group the active centers of components of the catalyst for reaction of oxidative dehydrogenation of methylcyclopentane which are responsible for formation of methylcyclopentadiene and methylcyclopentene. Total scheme of oxidative dehydrogenation of methylcyclopentane on these active centers is presented in Figure 2.

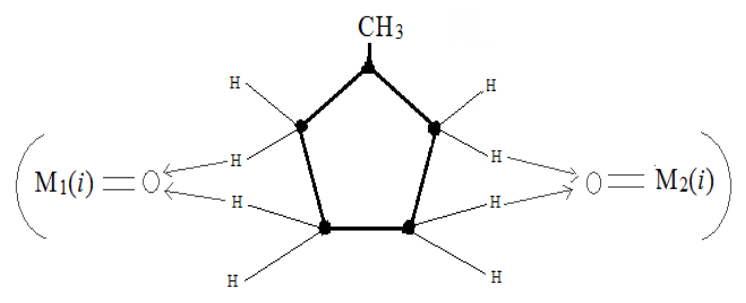

Fig. 2. Schematic representation of the reaction of oxidative dehydrogenation on an active center of modified clinoptilolite catalyst,CL-CuCrCoZn, $i$ - exchange cation, $i=1-4 ; 1-\mathrm{Cr}^{3+}, 2-\mathrm{Cu}^{2+}, 3-\mathrm{Zn}^{2+}, 4-\mathrm{Co}^{2+}$.

There are three types of active centers for reaction of oxidative dehydrogenation of 
methylcyclopentane into methylcyclopentadiene; $\left\{M_{1}(1), M_{2}(2)\right\}$ and $\left\{M_{1}(1), M_{2}(4)\right\}, \quad\left\{M_{1}(2)\right.$, $\left.\mathrm{M}_{2}(4)\right\}$. Because of solidity of bonds of cations; $\mathrm{Cr}^{3+}, \mathrm{Cu}^{2+}$ and $\mathrm{Co}^{2+}$ with oxygen atoms they have very strongly driving force of hydrogen atoms of methylcyclopentane, By adding $\mathrm{Zn}$ simultaneously increase forming molecules of methylcyclopentene with stabilized $\mathrm{Zn}=0$ which has relatively lower bonding energy (Figure 3 ).

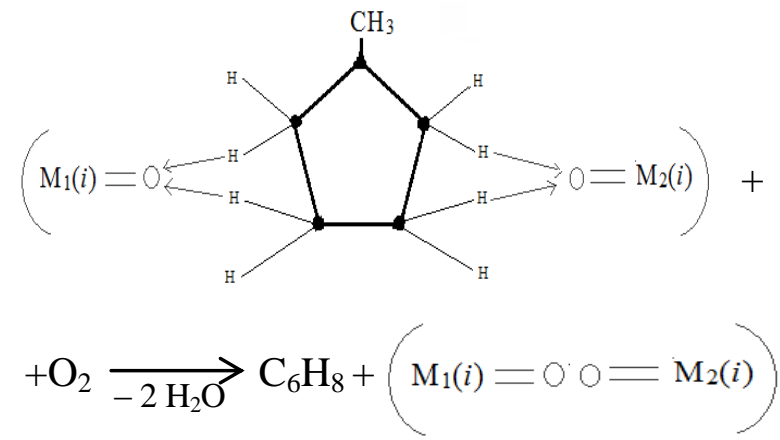

Fig. 3. Schematic representation of formation of methylcyclopentadiene on an active center $\left\{\mathrm{M}_{1}(1), \mathrm{M}_{2}(4)\right.$, $\}$ of modified clinoptilolite catalyst CL-CuCrCoZn.

By means of analysis of the experimental data and bonding energies of the components of the catalyst with oxygen atoms three types of active centers may be suggested for reaction oxidative dehydrogenation methylcyclopentane into methylcyclopentene; $\left\{\mathrm{M}_{1}(1), \mathrm{M}_{2}(3)\right\},\left\{\mathrm{M}_{1}(2)\right.$, $\left.\mathrm{M}_{2}(3)\right\},\left\{\mathrm{M}_{1}(4), \mathrm{M}_{2}(3)\right\}$.

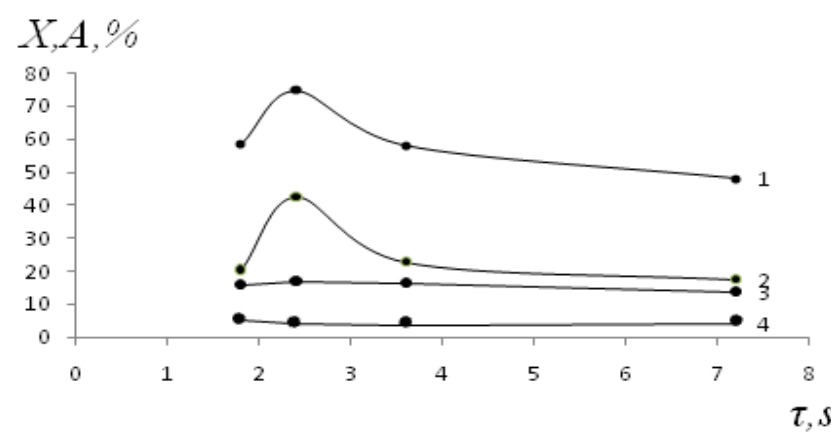

Fig 4. Dependence of oxidative dehydrogenation of methylcyclopentane on the average residence time, $\tau$; $1-$ conversion of methylcyclopentane, $\mathrm{X} \% ; 2$ - yield of methylcyclopentadiene, $\mathrm{A}_{4}, \% ; 3$ - yield of methylcyclopentene, $\mathrm{A}_{3}, \% ; 4-$ yield of benzene, $\mathrm{A}_{6}, \% ; T=360^{\circ} \mathrm{C}$, $\mathrm{C}_{6} \mathrm{H}_{12}: \mathrm{O}_{2}: \mathrm{N}_{2}=1.74: 1: 3.72$.

\section{Conclusion}

It should be noted that an advantage formation of methylcyclopentadiene depends on amount of active centers for corresponding reaction which depends on concentration and sequence of incorporating of cations by ionexchange. With the purpose of obtaining of methylcyclopentadiene the optimum succession incorporating of cation in clinoptilolite is $\mathrm{Cu}^{2+}(0.5$ mas\% $), \mathrm{Zn}^{2+}\left(0.2\right.$ mas \%), $\mathrm{Co}^{2+}(0.2$ mas $\%), \mathrm{Cr}^{3+}(0.2$ mas \%).

The source of the methylcyclopentane oxidative decomposition reaction products depends on the amounts and the concentration of effective centers for the reaction and the combination of ion exchange cations. Obtaining of methylcyclopentadien the optimum succession incorporating of cation in clinoptilolite is $\mathrm{Cu}^{2+}$ $(0.5 \mathrm{mas} \%) \rightarrow \mathrm{Zn}^{2+}(0.2 \mathrm{mas} \%) \rightarrow \mathrm{Co}^{2+}(0.2$ $\operatorname{mas} \%) \rightarrow \mathrm{Cr}^{3+}(0.2$ mas \%) $\rightarrow$ CL. From experimental data were confirmed that the kinetic scheme of the considered reactions over the active catalytic system does not proceed on a consecutive mechanism. From these experimental data, it can be accomplished that on the surface of the catalyst there different active centers obtaining which are responsible for the formation of the products of the reaction.

\section{References}

1. Process and catalyst for the preparation of methyl1,3-cyclopentadiene. Clarence L. Dulaney, Texas City, Tex., and Raymond A.Franz, Kirkwood, Mio, assignors to Monsanto Company, St. Louis, Mo., a corporation of Delaware No Drawing. Filed Mar. 8. 1962. Ser. No. 178. 2739 Claims. (CI. 260-666)

2. Aliyev A.M, Shabanova Z.A, Kerimov A.I, Bahmanov M.F, Aliyev F.V, Najaf-Guliyev U.M. Use of Metal-Zeolites as a Catalyst in Reaction of Oxidative Dehydrogenation of Naphthenes. Azerb. Chem. Journ. 2016. No 3. P. 63-74.

3. Matthew Johnson., David O'Connor, Paul Barnes C., Richard A. Catlow, Scott L. Owens, Gopinathan Sankar, Robert Bell.,Simon J. Teat, Richard Stephenson. Cation Exchange, Dehydration, and Calcination in Clinoptilolite: In Situ X-ray Diffraction and Computer Modeling. J. Phys. Chem. B. 2003. 107. P. 942-951.

4. Aliyev A.M., Abbasov M.Y., Shabanova Z.A., Ali-zadeh G.A., Bahmanov M.F., Najaf-Guliyev U.M., Huseynova T.I. A study of the kinetics and mechanism of the selective oxidative dehydrogenation reaction of cyclopentane to cyclopentadiene-1,3 over modified zeolite catalysts. Azerb. Chem. Journ. 2018. No 3. P. 11-20.

5. Hernandez M.A., Nitrogen-Sorption Characterization of the Microporous Structure of Clinoptilo- 
lite-Type Zeolites. J. Porous Materials. 2000. No 7. P. 443-454.

6. Iznaga I.R., Gomez A., Fuentes G.R., Aguilar A. B., Ballan, J.S., Natural clinoptilolite as an exchanger of $\mathrm{Ni}^{2+}$ and $\mathrm{NH}^{++}$ions under hydrothermal conditions and high ammonia concentration. Microporous and Mesoporous Materials. 2002. No 53. P. 71-80.

7. Koyama K., Takeushi Y. Clinoptilolite: the distribution of Potassium atoms and its role in thermal stability. Z.Kristallogr. 1977. V. 145. P. 216-239.
8. Boreskov G.K. Geterogennyi kataliz. M.: Nauka. $1986.300 \mathrm{~s}$.

9. Toyoshima I., SamorjaiG.A.Heats of chemisorptions of $\mathrm{O}_{2}, \mathrm{H}_{2}, \mathrm{CO}, \mathrm{CO}_{2}$ and $\mathrm{N}_{2}$ on polycrystalline and single crystal transition metal. Catal. Rev. 1979. V. 19. No 1. P. 105-159.

10. Armbruster Th. Dehydration mechanism of clinoptilolite and heulandite; single-crystal X-ray study of Na-poor, Ca-, K-, Mg-rich clinoptilolite at 100 K. Am. Maner. 1993. V.78. P. 260-264.

\section{METILTSIKLOPENTANIN METILTSIKLOPENTADIEN 1.3-Ө MODIFIKASIYA OLUNMUȘ SEOLIT KATALIZATORLARI ÜZəRINDə OKSIDLOŞDİRICI DEHIDROGENLəŞMəSI}

\section{A.M.Đliyev, M.Y.Abbasov, U.M.Nəcəf-Quliyev, Z.A.Şabanova, G.ə.əli-zadə, R.Y.Mirzəyeva}

Selektiv $\mathrm{C}-\mathrm{C}$ və $\mathrm{C}-\mathrm{H}$ əlaqələrinin aktivləşməsi ,müxtəlif qiymətli karbohidrogen əlavələrinin oksidləşdirici dehidrogenləşməsi proseslərinin alınması üçün vacib bir katalitik prosesdir. İstədiyiniz məhsulu yüksək məhsuldarlıqla əldə etmək üçün, katalizatorun dizayn edilməsi ilə reaksiya yolunun idarə olunması və reaksiya mexanizminin əsaslı anlaşılması və aydınlaşdırılması vacib şərtdir. $\mathrm{Bu}$ işdə metiltsiklopentanın oksidləşdirici dehidrogenləşmə reaksiyası üçün $\left\{\mathrm{Cu}^{2+}(0.5\right.$ mas.\%), $\mathrm{Zn}^{2+}\left(0.2\right.$ mas.\%), $\mathrm{Co}^{2+}\left(0.1\right.$ mas.\%), $\mathrm{Cr}^{3+}(0.1$ mas.\%) \} hissəcikləri və (CL) klinoptilolit zeolitləri birloşdirərək heterogen katalizatorları hazırladıq. Katalizatorun kombinasiyalarından asılı olaraq, dehidrogenləşmə reaksiyasının yollarına, izomerləşmə ilə həlqənin açılmasına, hidrogenləşmə və dehidrogenləşmə ilə $\mathrm{C}_{5}$ tsiklik həlqənin $\mathrm{C}_{6}$ tsiklik həlqəyə (tsikloheksan və benzol ) böyüməsi kimi müxtəlif məhsulların yüksək çıxımla alınmasına nəzarət etmək olar. Metiltsiklopentanın konversiyas $360^{\circ} \mathrm{C}$-də HY zeolitində araşdırıldı. Metiltsiklopentanın metiltsiklopentadinə selektiv oksidləşdirici dehidrogenləşmə reaksiyasında klinikoptilolitin katalitik fəaliyyəti eksperimental olaraq ölçülmüşdür. $\mathrm{Zn}$ əlavə edilməsi katalitik fəaliyyətin sabitliyini artırır və selektivliyin fərqli dəyişilməsinə səbəb olur. Zn miqdarını artdıqda metiltsiklopentanın metilsilopentadienə dehidrogenləşməsi maksimum dərəcəyə çatır və metilsilopentanın benzola qədər dərin dehidrogenləşməsi təxminən sabit qalır. Bu tədqiqat reaksiya yollarını idarə etmək üçün heterogen katalizatorun yaradılması üçün praktik və əsaslı fikirlər təqdim edəcəkdir.

Açar sözlor: Metilstiklopentan, katalitik dehidrogenlaşmə, metiltsiklopenten, etiltsiklopentadien, klinoptilolit.

\section{ОКИСЛИТЕЛЬНОЕ ДЕГИДРИРОВАНИЕ МЕТИЦИКЛОПЕНТАНА В МЕТИЦИКЛОПЕНТАДИЕН-1,3 НА МОДИФИЦИРОВАННЫХ ЦЕОЛИТНЫХ КАТАЛИЗАТОРАХ}

\section{А.М.Алиев, М.Я.Аббасов, У.М.Наджаф-Кулиев, З.А.Шабанова, Г.А.Али-заде, Р.Ю.Мирзоева}

Селективная активация $\mathrm{C}-\mathrm{C}$ - и $\mathrm{C}-\mathrm{H}-$-вязей является важной стадией каталитических процессов окислительного дегидрирования углеводородов с целью получения ценных продуктов. Для получения целевого продукта с высоким выходом управление направлением реакции путем конструирования катализатора фундаментальные знания и представления о механизмах реакции являются необходимыми положениями. В настоящей работе нами представлены результаты исследований по конструированию гетерогенных катализаторов путем сочетания $\left\{\mathrm{Cu}^{2+}\left(0.5\right.\right.$ масс.\%), $\mathrm{Zn}^{2+}\left(0.2\right.$ масс.\%), $\mathrm{Co}^{2+}\left(0.1\right.$ масс.\%), $\mathrm{Cr}^{3+}(0.1$ масс.\%) $\}$ катионов и клиноптилолитных цеолитов для реакции окислительного дегидрирования метилциклопентана. В зависимости от присоединения катализаторов пути реакций дегидрирования, изомеризация с открытием циклов и гидрирования с расширением циклов и дегидрирования $\mathrm{C}_{5}$-циклического кольца в $\mathrm{C}_{6}$-циклического кольца (т.е. циклогексан и бензол) могут контролироваться для получения различных продуктов с высокими выходами. Конверсия метилциклопентана исследована на $\mathrm{HY}$ цеолите при $360^{\circ} \mathrm{C}$. Каталитическая активность клиноптилолита в реакции селективного окислительного дегидрирования метилциклопентана в метилциклопентадиен была измерена экспериментально. Добавление Zn повышает стабильность каталитической активности и вызывает различные изменения селективности. При увеличении содержания $\mathrm{Zn}$ дегидрирование метилциклопентана в метилциклопентадиен проходит через максимальное и глубокое дегидрирование метилциклопентана в бензол и остается приблизительно постоянным. Это исследование дает практические и фундаментальные знания для разработки гетерогенного катализатора для регулирования путей реакции.

Ключевые слова: метилииклопентан, каталитическое дегидрирование, метилииклопентен, метилииклопентадиен, клиноптилолит. 